\title{
Igreja Local
}

Mario de França Miranda

\section{Premissa}

Podemos tratar da realidade da Igreja Local de dois modos. Primeiramente oferecendo uma exposição de pronunciamentos do magistério da Igreja que determinam de antemão os marcos teóricos da temática segundo, naturalmente, o peso dogmático dos mesmos. Chegamos assim a um texto claro e seguro, bem sistematizado, porém demasiado teórico e idealizado quando confrontado com a realidade eclesial concreta para a qual buscamos uma orientação. A outra modalidade de abordagem, que será a nossa, procura refletir a temática sem prescindir na própria reflexão do contexto real no qual ela acontece. Esta opção dificulta e complica o estudo, mas resulta mais prática e eficaz por ter em consideração os componentes reais da atual situação eclesial, mesmo que não sejam diretamente de cunho teológico. Nossa abordagem se situa na mesma linha de outras elaborações teológicas que buscam responder ao desafio da modernidade ao apontar para a base antropológica das verdades da fé, como do fato da revelação, da pessoa de Jesus Cristo, da manifestação da Santíssima Trindade, da existência dos sacramentos, da realidade complexa que é a salvação cristã, e, por fim, da própria Igreja como realidade humano-divina.

Numa parte introdutória examinaremos o nosso contexto atual a partir do qual estudaremos o tema proposto e veremos que pressupostos ele exige para que nossa reflexão seja mais objetiva e isenta. Em seguida exporemos o que constitui a Igreja a partir dos dados da revelação, a saber, os componen- 
tes teológicos imprescindíveis para haver Igreja sem mais. Numa terceira parte examinaremos a Igreja como comunidade de homens e mulheres que aceitam a revelação de Deus na pessoa de Jesus Cristo, e o que daí resulta para uma compreensão da Igreja Local. Posto isto poderemos abordar melhor tanto a relação da Igreja Local com a Igreja Universal numa quarta parte, quanto a relação da Igreja Local com os movimentos numa quinta e última parte.

\section{Introdução}

\section{A sociedade em que vivemos}

A situação em que se encontra uma sociedade não deixa de refluir para dentro da Igreja, pois a Igreja faz parte desta sociedade concreta com suas tensões, expectativas, desafios, realizações e fracassos. Não pretendemos descrever aqui como se apresenta hoje a complexa situação da nossa sociedade. Apenas mencionaremos algumas características que incidem diretamente no nosso tema. A sociedade pluralista de nossos dias, embora de fato dominada pelo fator econômico, permite ao indivíduo conviver com uma oferta múltipla de visões da realidade e padrões de comportamento ao contrário do que se dava no passado, quando devia se submeter aos quadros socioculturais legados por seus antecessores. Esta situação nova lhe permite acolher alguns elementos e assim orientar sua vida de modo livre e pessoal. Daí sua dificuldade com tudo o que lhe vem imposto baseado apenas na autoridade ou na tradição, sem apresentar uma fundamentação convincente e sem ter em conta sua pessoa concreta. Daí também sua vontade de participar no processo de construção da sociedade, pois está convencido de que esta última não desceu pronta do céu, mas foi produção humana.

Também a sociedade pluralista se apresenta como uma sociedade de diálogo e de consenso, pois só assim torna possível a convivência pacífica de grupos humanos diferentes que devem conhecer e respeitar os demais. A participação efetiva no futuro da sociedade é um forte anseio de nossos contemporâneos.

Por outro lado a enorme massa de conhecimentos hoje disponível, agravada por sempre novas descobertas e novas perspectivas de leitura da realidade, acaba por provocar rápidas e sucessivas mudanças socioculturais. Deste modo os quadros explicativos e os padrões de conduta do passado se tornam questionados, não mais servem para orientar o indivíduo nesta sociedade tensa, acelerada, instável, e conseqüentemente em crise. Todos os setores sociais sofrem este desgaste e passam por certa crise de identidade, como a família, a universidade, a vida política, a atividade profissional. Também a Igreja não 
escapa desta situação. Muitos de seus problemas se originam na própria sociedade em crise. Poderíamos ainda mencionar brevemente a enorme produção de bens da sociedade industrializada moderna que devem ser adquiridos para que as fábricas continuem funcionando e a sociedade continue vivendo. $\mathrm{O}$ consumismo se torna uma febre que assola a atual humanidade e a preocupação mais abrangente de tudo experimentar, de tudo gozar, de ser feliz a todo custo, acaba por fazer desaparecer da vida social os valores transcendentes, a visão de uma outra realidade além desta que vêem nossos olhos. Vivemos uma época de profunda crise de fé, de ausência de referências substantivas e não apenas funcionais, de busca desenfreada por uma religiosidade de auto-ajuda.

Observemos ainda que o progresso dos meios de transporte e dos meios de comunicação aproximou as diversas partes do planeta e permitiu o surgir de uma cultura globalizada, fortemente incentivada pela economia. Em reação, os países experimentam hoje uma intensa afirmação de suas culturas regionais, de seus valores e de suas tradições históricas que constituem suas raízes. Este fenômeno incidirá também sobre a comunidade eclesial como veremos.

\section{A liberdade interior}

Um outro elemento que deve ser considerado, antes mesmo de entrarmos em nosso tema, diz respeito à objetividade de nossa reflexão. Pois experimentamos, todos nós, tensões na Igreja, afirmações diferentes e até contrárias, juízos divergentes sobre os mesmos fatos, linhas de ação em luta, embates teológicos. No fundo é o refluxo do pluralismo presente na sociedade, com todos os fatores que o motivaram, que também emerge na Igreja, já que seus membros são cidadãos desta sociedade e respiram esta mesma cultura pluralista. Além disso, nossa temática que visa a elucidar as relações entre Igreja Local, Igreja Universal e Movimentos incide inevitavelmente na esfera do poder, como comprova a própria história da Igreja. E o desejo de poder constitui, sem dúvida, uma das paixões mais fortes e camufladas dos esforços humanos.

Assim o nosso tema pressupõe que sejam examinadas as condições mentais de quem o estuda. Pois subjacente a uma argumentação teórica fechada, defensiva, radical, arrogante, pode existir uma ausência de liberdade interior por estar em jogo o poder, a honra, a jurisdição, a eminência. Se entendermos por ideologia num sentido estrito a justificação racional a serviço de relações de dominação, podemos então apontar no interesse ideológico um sério obstáculo para nosso estudo. Já Santo Inácio de Loyola em seus Exercícios Espirituais, que constituem uma verdadeira pedagogia da liberdade interior, procura levar o exercitante a uma purificação dos afetos desordenados, sobretudo através da meditação das "duas bandeiras" (EE. 136-148). Só então será 
ele um sujeito idôneo capaz de discernir retamente a vontade de Deus para sua vida.

O teólogo norte-americano Michael J. Buckley ${ }^{1}$ vai buscar inspiração em S. João da Cruz, o qual apresenta três conselhos para se entrar na noite dos sentidos ${ }^{2}$. Para Buckley tais orientações valem também para teólogos e autoridades eclesiásticas. Primeiramente trata-se de seguir em tudo o modo de proceder de Jesus Cristo, através do estudo e da meditação de sua vida. Deste modo o teólogo adquire o contexto cristão que guia sua reflexão. Em segundo lugar ele deve buscar sempre como meta puramente a glória de Deus ou, como diríamos hoje, o Reino de Deus. Qualquer inclinação em vista de obter ou manter poder e prestígio, honra e preeminência, jurisdição e dominação, seja em teoria, prática ou mesmo simbolicamente, deve ser afastada. Sua presença, mesmo latente, aponta para um desejo desordenado de poder por parte dos que detêm o poder, ou por ele aspiram ou, ainda, estão ressentidos por não ter conseguido alcançá-lo. Em terceiro lugar, sabendo que tal inclinação se camufla de muitos modos deve procurar voltar-se para o que significa serviço autêntico e escondido, serviço desprovido de poder e prestígio. Esta atitude possibilita se chegar à autêntica vontade de Cristo para sua Igreja ${ }^{3}$ através de uma ascética hermenêutica da suspeita, como observa este autor ${ }^{4}$. Igualmente o teólogo J. Ratzinger já havia notado quão importante é a afirmação de Cristo aos apóstolos por ocasião da querela sobre quem seria o maior no Reino dos céus: o maior seja o menor e servo de todos ${ }^{5}$. Somente a liberdade interior nos livra da ambição, do medo, do desejo de granjear favor ou descarregar ressentimentos para podermos tratar objetivamente questões relacionadas com o poder na Igreja.

\section{A finalidade salvífica}

Assim como a encarnação do Verbo de Deus estava toda ela voltada para a salvação da humanidade, assim também a Igreja de Cristo só se justifica enquanto está a serviço desta salvação ao longo da história humana. Toda a vida de Jesus com sua paixão, morte e ressurreição esteve a serviço do Reino de Deus. Do mesmo modo tudo o que constitui a Igreja alcança sua

\footnotetext{
${ }^{1}$ M. J. Buckley S.J., Papal Primacy and the Episcopate. Towards a relational Understanding, Crossroad Herder, New York, 1998, p.27-31.

${ }^{2}$ São João da Cruz, Subida do Monte Carmelo I cap. 13, BAC, Madrid, 1964, p.391.

${ }^{3}$ João Paulo II, Ut unum sint, n. 96.

${ }^{4}$ Buckley, ob. cit. p. 30.

5 J. Ratzinger, "Primat, Episkopat und successio apostólica", em: K. Rahner-J.Ratzinger, Episkopat und Primat, Herder, Freiburg, 1961, p. 59.
} 
razão de ser e seu sentido na medida em que leva a mensagem evangélica e a práxis cristã, para seus contemporâneos. A Igreja é deste modo uma realidade não voltada para si, mas para a sociedade na qual deve ser sal, luz e fermento.

Esta verdade explica porque a Igreja sofre mudanças em sua dimensão institucional e apresenta configurações diversas ao longo dos anos. Neste caso busca-se sempre adaptar sua estrutura a um melhor desempenho de sua missão salvífica. Igualmente temos aqui um critério seguro para abolirmos estruturas que se revelem obstáculos a esta missão, sobretudo as que não nasceram de exigências salvíficas, mas do egoísmo, da vontade de poder, do comodismo e da vaidade humana. Permanece ainda um problema em busca de solução o critério decisivo para distinguir, em alguns casos, o que na instituição se deve à revelação e o que não passa de mera produção humana podendo assim ser suprimida ou modificada sem maiores problemas.

$\mathrm{Na}$ mesma linha se deve ter claro que a Igreja como sacramento da salvação não o é apenas pelas verdades que proclama, pelos preceitos éticos que propugna, ou pelos sacramentos que administra. Ela o é, sobretudo, pelo testemunho de vida de seus membros, pelos valores cristãos presentes na comunidade, especialmente o amor fraterno, pelas relações humanas vividas diferentemente daquelas do mundo. Tudo o que possa favorecer a qualidade de vida cristã de seus membros deveria ser assumido pela Igreja. Do mesmo modo as tradições e estruturas criadas no passado e que hoje dificultam uma autêntica vivência cristã deveriam ser tranqüilamente descartadas, embora gradativamente, pois sabemos quão difícil é para uma geração abandonar hábitos, concepções e práticas, que marcaram sua vida.

Deste modo podemos afirmar que a Igreja muda (e deve mudar) em sua configuração histórica apenas para permanecer fiel a sua identidade de mediação salvífica. Perder de vista este imperativo significa absolutizar o relativo, eternizar o histórico, fixar o provisório, impedir o surgimento de novas pastorais e estruturas eclesiais condizentes com a realidade histórica. Não nos deve admirar que uma nova configuração institucional se inspire na atual sociedade, tal como aconteceu no passado ${ }^{6}$, embora sempre na fidelidade à "vontade de Cristo para sua Igreja", ou como expressamos, à finalidade salvífica desta mesma Igreja.

${ }^{6}$ De uma já extensa bibliografia mencionemos Y. Congar, L'Église de saint Augustin à l'époque moderne, Cerf, Paris, $1997^{2}$ e G. Lafont, Imaginer l'Église catholique, Cerf, Paris, 1995. 


\section{A Igreja Local na perspectiva de Deus}

Primeiramente uma palavra sobre a expressão "Igreja Local". Encontramos nos textos do Concílio Vaticano II tanto a expressão "Igreja Particular" (designando especialmente dioceses) como também o termo "Igreja Local" (designando dioceses, patriarcados e também comunidades em torno da eucaristia $)^{7}$. O Novo Código de Direito Canônico preferiu a expressão "Igreja Particular" para designar a diocese, fato este lamentado por bons eclesiólogos, que preferem falar de "Igreja Local". . De fato, a raiz do termo "particular" é parte, o que pode gerar uma compreensão errada da Igreja Local como se esta fosse parte da Igreja Universal. Por esta razão preferimos a expressão "Igreja Local" para comunidades eucarísticas, dioceses ou conjunto de dioceses (regionais, Conferências Episcopais, Conferências Episcopais continentais). A história da Igreja apresenta exemplos desta Igreja Local tendo uma Igreja Principal ou Metropolita que em regime sinodal regulamentava questões como sagração de bispos, divisões de dioceses, normas canônicas e litúrgicas, disciplina do clero e dos leigos. Naturalmente tinha grande peso o entorno cultural que moldava uma configuração própria para a Igreja Local ${ }^{9}$.

Ao afirmarmos ser a Igreja o Povo de Deus, o Corpo de Cristo, o Templo do Espírito Santo, a Comunhão de todos seus membros com Deus e entre si, estamos caracterizando-a a partir de Deus. Estas afirmações têm sua fonte no testemunho do Novo Testamento, na própria revelação de Deus. Podemos também afirmar que elas deitam suas raízes numa realidade teologal vivida e experimentada pelos primeiros cristãos. Observemos ainda que a Igreja existe por pura iniciativa de Deus, primeira, gratuita, fundante. Jamais uma interpretação da Igreja que prescinda da fé conseguirá determinar corretamente sua identidade.

O Decreto do Concílio Vaticano II Christus Dominus (n.11) assim define a Igreja Local: "Diocese é a porção do Povo de Deus confiada a um Bispo para que a pastoreie em cooperação com o presbitério. Assim esta porção, aderindo ao seu pastor e por ele congregada no Espírito Santo medi-

\footnotetext{
${ }^{7}$ H. Legrand, "La réalisation de l'Église en un lieu", em: Initiation à la pratique de la théologie III, Cerf, Paris, 1993, p.145s.

${ }^{8}$ Ver S. Dianich, Trattato sulla Chiesa, Queriniana, Brescia, 2002, p.345s, que assume o termo "Igreja Local" e ainda menciona E.Lanne, J.Ratzinger, A.Amato, F.Klostermann, J.A.Komonchak como sendo de igual parecer.

${ }^{9}$ G. Greshake, "Zwischeninstanzen zwischen Papst und Ortsbischöfen", em: H.MüllerH.J.Pottmeyer (Hrsg.), Die Bischofskonferenz: Theologischer und juridischer Status, Düsseldorf, 1989, p. 98ss.
} 
ante o Evangelho e a Eucaristia, constitui uma Igreja Particular. Nela verdadeiramente reside e opera a Una, Santa, Católica e Apostólica Igreja de Cristo". Aqui temos os componentes essenciais da Igreja Local. Vejamos.

Primeiramente ela é congregada pelo Pai (que tem a iniciativa de chamá-la a existência) por meio de Jesus Cristo (cuja vida, palavras e ações revelam o gesto salvífico de Deus, atraindo homens e mulheres a viverem como Ele) no Espírito Santo (a saber, inspirados, capacitados e fortalecidos pelo mesmo Espírito presente e atuante na pessoa de Jesus Cristo). Enquanto todos participam dos mesmos bens salvíficos, da própria existência divina, estão eles em comunhão com Deus e com os demais, como tão expressivamente descreve São João (1Jo 1,1-3). A eucaristia é a expressão sacramental desta comunhão (1Cor 10,16s).

Outro componente da Igreja Local é a proclamação do Evangelho. Já dizia Paulo que "a fé vem da pregação, e a pregação é o anúncio da Palavra de Cristo" (Rm 10,17). A Igreja se constitui pela adesão dos que ouvem a Palavra e a acolhem na fé. Como dizia Santo Agostinho: "Pregaram a palavra da verdade e geraram as Igrejas" (PL 36,508). Esta proclamação do Evangelho por parte da Igreja é ampla, pois consiste em transmitir "doutrina, vida e culto", ou mais concisamente "tudo o que ela é, tudo o que crê" (Dei Verbum 8).

A Igreja Local é presidida pelo bispo. Embora toda ela seja ministerial, apostólica e missionária, tem o bispo a presidência da mesma, coadjuvado pelo seu presbitério e em comunhão com as demais Igrejas. Sendo assim é ele o responsável primeiro pela santificação, governo e ensino na Igreja Local. Seu carisma é o de supervisionar os demais carismas da comunidade. Deste modo o fato em si de ser a Igreja uma comunidade hierárquica ou com diversidade de membros não exclui a participação de todos em sua finalidade salvífica. O que sucedeu no passado com certo clericalismo dominante que reduzia os demais membros a um papel meramente passivo, embora se explique por razões históricas, não corresponde ao que deve ser a Igreja enquanto comunidade ordenada, conforme atesta o Vaticano II e, mais recentemente, o Documento de Aparecida.

A ação do Espírito na Igreja Local. O acolhimento de Jesus Cristo através da pregação da Palavra, a formação da comunidade dos fiéis, a celebração eucarística, a práxis efetiva da caridade, tudo isto acontece por força do Espírito. "Todos nós fomos batizados em um só Espírito para formarmos um só corpo" (1Cor 12,13). O Espírito, portanto, gera comunhão (2Cor $12,13 ; \mathrm{Fl} 2,1)$. O princípio último de nosso relacionamento com Deus e entre nós é o mesmo, a saber, o Espírito Santo. Neste sentido podemos afirmar que todo cristão ou todo membro da Igreja é sem mais um carismático. "Nin- 
guém pode dizer Jesus é o Senhor, a não ser pelo Espírito Santo" (1Cor 12,3). Esta afirmação vale também para aquele que anuncia a Palavra salvífica. A fé comporta necessariamente uma dimensão mística, que subjaz à constituição da própria Igreja; daí ser contada entre os carismas (1Cor 12,9). Portanto, enquanto comunidade dos que crêem a Igreja é fundamentalmente carismática.

Toda a ação do Espírito nos cristãos é levá-los a viver para Cristo (Rm 14,7), é possibilitar a adesão a Cristo na fé (1 Cor 12,3), é comunicar-lhes a atitude filial de Cristo ( $\mathrm{Rm} 8,14$; Gl 4,6), é fazê-los viver o amor fraterno (Gl $5,22-26)$. Deste modo a obra salvífica de Deus se realiza pela dupla missão do Filho e do Espírito. Esta verdade vale também para a Igreja. Jesus Cristo é o fundador histórico-visível da Igreja, o Espírito Santo é a vida que a anima ( $L G 7)$. Assim ela está vinculada tanto à encarnação do Verbo como ao Pentecostes do Espírito, quando então ela se constitui como comunidade de fiéis e de testemunhas. Daí ser o Espírito co-instituente da Igreja. Mediante sua ação os apóstolos iniciam a atividade missionária, elegem Matias para o grupo dos doze e determinam aspectos institucionais exigidos pela situação presente. Podemos assim afirmar que o Espírito Santo não vem somente animar uma instituição já totalmente determinada em suas estruturas ou nos grupos nela presentes. Mas sua presença atuante pode despertar novas espiritualidades, novas pastorais, novas estruturas para que, renovada, a Igreja possa melhor responder aos desafios postos à sua missão salvífica.

Uma Igreja pneumatológica e missionária. Enquanto a Igreja é constituída por homens e mulheres animados pelo mesmo Espírito Santo, todos nela são sujeitos. São pessoas conscientes e responsáveis em sua fé e em seu proceder, vivem histórias próprias, são dotadas de carismas e de dons pessoais que contribuem para a comunidade e para a construção e configuração concreta da Igreja. Portanto, não são membros passivos da comunidade, mas transmitem a outra geração uma realidade viva, a saber, a salvação de Jesus Cristo experimentada em suas próprias existências. Daí o Concílio Vaticano II considerar toda a Igreja ministerial e afirmar que "todo leigo, em virtude dos próprios dons que lhe foram conferidos, é ao mesmo tempo testemunha e instrumento vivo da própria missão da Igreja" ( $L G 33$ ). Daí também reconhecer que tais ministérios são necessários à construção da comunidade eclesial e que "devem ser por todos diligentemente fomentados e cultivados" ( $A G 15)$.

Se o sentido último da Igreja consiste na missão de levar à humanidade a salvação de Jesus Cristo e se esta mesma Igreja é constituída por uma comunidade de seguidores de Cristo, então deve a comunidade eclesial ser toda ela missionária. É todo o Povo de Deus que é chamado a testemunhar e 
celebrar os valores evangélicos no culto e na caridade vivida, na proclamação da Palavra e no serviço aos demais. A afirmação conciliar do "sacerdócio comum dos fiéis" ( $L G 10)$ implica uma outra concepção do sacerdócio, diversa daquela do Antigo Testamento. Jesus Cristo foi o sacerdote da Nova Aliança não pela oferta de sacrifícios de animais, mas pela entrega de sua própria vida (Hb 5,10;7,11). Nesta nova visão toda a comunidade cristã é sacerdotal (1Pd 2,9; Ap 1,6) e o verdadeiro culto consiste na oferta da própria vida a Deus $(\mathrm{Rm} \mathrm{12,1s)}$ ao fazer o bem aos demais $(\mathrm{Hb} 13,16)$. O fundamental na comunidade cristã é a fé vivida celebrada no batismo e na eucaristia. Todos são "irmãos em Cristo", todos constituem a comunidade, todos são responsáveis, todos são ativos na propagação do Reino, todos devem participar a seu modo das orientações e das decisões da Igreja. Naturalmente a recepção desta eclesiologia que se queira efetiva exige não só mudanças na mentalidade de muitas autoridades como também transformações institucionais como aparece claramente do recente Documento de Aparecida ${ }^{10}$.

\section{A Igreja Local como comunidade humana}

Vamos partir de uma verdade teológica que terá grande conseqüência para o nosso estudo sobre a Igreja Local. O gesto salvífico de Deus em favor da humanidade pressupõe para chegar a sua meta o acolhimento na fé por parte do ser humano. Sem a fé, embora possibilitada pelo próprio Deus (Espírito Santo), não haveria revelação e nem afirmaríamos a divindade de Jesus. Logo a fé pertence ao próprio conteúdo do que expressamos como Palavra de Deus. Do mesmo modo, dada a importância da comunidade eclesial para a nossa fé, como vimos anteriormente, podemos igualmente afirmar que a revelação pressupõe a Igreja enquanto comunidade dos que crêem ${ }^{11}$.

Mas esta comunidade eclesial vive num contexto sociocultural determinado, com sua linguagem, suas expectativas, seus problemas, seus valores, e é necessariamente em seu interior que será captada e acolhida a oferta salvífica de Deus. Pois a Palavra de Deus não cai num vazio antropológico, num ser humano abstrato ou numa sociedade indeterminada. Ela, sendo sempre a mesma, só é alcançada na mediação histórica e mutável na qual se faz presente. A fé da comunidade, da qual participa a fé do indivíduo, tende naturalmente a se expressar e se transmitir para outros por meio de doutrinas, de ritos e práticas, de organizações sociais, de funções e papéis, que significam a institucionalização dessa experiência salvífica primeira. Toda religião

\footnotetext{
${ }^{10}$ Ver M. de França Miranda, "O desafio de Aparecida. Uma configuração eclesial para a América Latina”, Revista Eclesiástica Brasileira 59 (2009) p. 77-102.

${ }^{11}$ A. Dulles, Models of Revelation, Orbis, New York, 1996 , p. 220.
} 
busca se institucionalizar para poder perdurar. Esse processo está a serviço do encontro salvífico do ser humano com Deus, como mediação que o facilite e o promova.

Uma comunidade humana só é tal e distinta de outros grupos humanos quando apresenta quatro componentes estreitamente relacionados entre si e que devem ser comuns a todos os seus membros. Primeiramente uma experiência partilhada por todos, o que implica situações existenciais determinadas com seus respectivos desafios atingindo a todos e plasmando assim uma história comum. Em seguida, seus membros devem chegar a compreensões da realidade também comuns, que possibilitem avaliações comuns. E, finalmente, se requer decisões comuns em vista de valores comuns para que esta comunidade se torne efetiva. Deste modo, uma comunidade nasce e morre na medida em que uma comunidade de experiência, de compreensão, de avaliação e de decisão nasce e morre ${ }^{12}$.

Contudo, tais elementos não surgem de repente, nem brotam do nada. Enquanto comunidade humana, ela é, constitutivamente, uma comunidade de sentido e de valor, pois se compreende e se constitui sempre no interior de uma linguagem recebida, de um horizonte cultural transmitido, de uma interpretação determinada dos eventos. Só assim é capaz de compreender a realidade e de estabelecer sua escala de valores. Habitamos um mundo social criado por outros, com sua linguagem, expectativas, símbolos, papéis, instituições, realizações políticas e econômicas. E só em seu interior podemos entender e avaliar o mundo à nossa volta.

$\mathrm{O}$ evento Jesus Cristo (suas ações, suas palavras, sua morte e sua ressurreição) representa o componente transcendente da comunidade eclesial, agregando e vivificando seus membros. Ele abre para a humanidade um novo quadro interpretativo da realidade que possibilitará experiências comuns, compreensões comuns, avaliações comuns e compromissos comuns, constituindo assim a Igreja. Trata-se de uma comunidade com identidade própria, a saber, a realização social da modalidade de vida inaugurada por Jesus Cristo, manifestando a salvação oferecida em Cristo e interpelando os demais grupos humanos a viverem o desígnio de Deus para a humanidade. Nela estão presentes não só a pessoa de Jesus Cristo, mas também as Escrituras, a Tradição, os dogmas, a liturgia, os santos, etc.

Observemos ainda que todo este patrimônio que garante a identidade da Igreja deve ser recebido e apropriado por cada geração dentro de seu contexto sociocultural respectivo e dotado de uma linguagem própria. Só assim a mensagem salvífica pode ser captada e vivida por uma geração de cristãos,

${ }^{12}$ J.A.Komonchak, Foundations in Ecclesiology, Fred Lawrence, Boston, 1995, p. 83-88. 
só assim ela pode ganhar vida e penetrar a realidade social. Deste modo, a comunidade cristã sempre se constitui e se compreende com as representações mentais, com as categorias sociais, com as estruturas organizativas presentes e atuantes em seu respectivo contexto sociocultural. Não nos deve admirar, portanto, que a Igreja no curso de sua história, tenha se apropriado de elementos institucionais à mão para se organizar como comunidade. $\mathrm{E}$ nem, que esta sua dimensão institucional tenha se transformado ao longo dos séculos, devido às mudanças na própria sociedade. Voltamos a repetir: a Igreja muda para conservar sua identidade e sua finalidade salvífica. Neste sentido podemos dizer que ela se auto-institucionaliza no correr da história ${ }^{13}$.

Recebemos o patrimônio salvífico das gerações anteriores, patrimônio este naturalmente moldado conforme as situações existenciais e contextos socioculturais daquelas gerações. Como a sociedade se transforma, pode toda esta riqueza de fé pouco dizer a nossos contemporâneos, por experimentarem outros desafios, outras linguagens, outras organizações sociais que impedem que esta riqueza seja real e concretamente vivida por eles. Do ponto de vista institucional, haverá uma crise na comunidade eclesial (como, aliás, em outros grupos sociais: família, escola, mundo político, etc.) sempre que as experiências, as compreensões, as avaliações e os compromissos comuns dos membros da comunidade não mais se encontrem na instituição concreta que lhes foi legada. Pois suas expressões e práticas, formulações doutrinais e morais, dinamismos e estruturas não mais se adequam à realidade vivida pelos membros da comunidade, que lhes apresenta novos desafios, novos contextos, novas mentalidades, que exigem nova configuração local ${ }^{14}$.

Portanto, a razão decisiva para uma configuração eclesial afinada com seu respectivo contexto sociocultural vem a ser a própria finalidade salvífica da Igreja. Vivemos hoje uma era de pós-cristandade quando a adesão à fé cristã resulta de uma opção livre e consciente. E a fé constitui o fundamento da Igreja ${ }^{15}$. Dificultar a fé dos cristãos é atingir a própria sobrevivência da

\footnotetext{
${ }^{13}$ W. Klausnitzer, Der Primat des Bischofs von Rom, Herder, Freiburg, 2004, p. 513s. O autor argumenta a favor do primado, mas menciona também a consciência da Igreja primitiva como uma comunidade própria, constituída de judeus e gentios, a formação do cânon neotestamentário, a formulação cristológica do Concílio de Calcedônia, a determinação dos sete sacramentos, e ainda verdades mais recentes como os direitos humanos, a liberdade de consciência, a liberdade religiosa, contidas na própria mensagem cristã.

${ }^{14} \mathrm{O}$ aparente embate entre fé e mundo pode ser, de fato, a oposição entre a fé plasmada e vivida no século XIII com a fé do século XX. Ver J. Ratzinger, Dogma e Anunciação, Paulus, S. Paulo, 1977, p.143.

15 Tomás de Aquino, Comentário aos Colossences c.I, 1.5: "Fides est sicut fundamentum, ex cujus firmitate tota firmatur ecclesiae structura".
} 
Igreja. Daí a enorme importância da Igreja Local em nossos dias. Cabe a ela mediatizar a salvação de Jesus Cristo para seus contemporâneos. Esta adequada configuração é tarefa da Igreja Local, bispo e fiéis, conforme recomendam tanto o Concílio Vaticano II, quanto o magistério pontifício. Ela é também fruto da ação do Espírito Santo ao inspirar novos modos de viver o seguimento de Cristo, novas estruturas adequadas à vivência cristã da comunidade, novas dimensões da nossa fé. Fonte dos carismas Ele é não só princípio de unidade, mas também de diversidade. Sentimos dificuldade em aceitar tal verdade devido ao peso do passado (centralismo romano, uniformidade como unidade, nostalgia da cristandade).

A Igreja Local deve assumir as características próprias de cada povo ou região, oferecendo às demais Igrejas os seus dons em vista de uma maior plenitude ( $L G 13)$. Para isso deverá se inserir no contexto sociocultural onde se encontra $(A G 10)$, aproveitando a sabedoria, as artes e as instituições dos povos para expressar a glória do Criador $(A G 22)$. A catolicidade da Igreja Universal não é apenas geográfica, mas qualitativa, ao respeitar as diversidades locais. Preocupar-se somente com o patrimônio recebido das gerações anteriores sem ter em devida consideração as pessoas concretas (com suas matrizes culturais e seus desafios locais) é uma das causas da funesta separação entre fé e vida, tão espalhada em nossos dias. É preciso que a fé apareça como resposta às interpelações hodiernas, pois só então ela será significativa e atraente numa cultura que rejeita imposições.

\section{Igreja Local e Igreja Universal}

O Concílio Vaticano II considera a Igreja Universal como uma comunhão de Igrejas. Ao afirmar que "a Igreja de Jesus Cristo está verdadeiramente presente em todas as legítimas comunidades locais de fiéis", mesmo que sejam "pequenas e pobres, ou vivendo na dispersão" ( $L G 26)$. O fundamento desta afirmação é oferecido pelo mesmo Concílio: todas elas são "formadas à imagem da Igreja Universal, nas quais e pelas quais subsiste a Igreja Católica una e única" (LG 23). Deste modo assevera que na Igreja Local "está verdadeiramente presente e ativa a Una, Santa, Católica e Apostólica Igreja de Cristo" ( $C D$ 11). As Igrejas Locais não são distintas da Igreja Universal, mas esta última somente existe nelas e por elas. Por conseguinte, a Igreja Universal não consiste na soma ou na confederação de Igrejas Locais, que pudessem ser consideradas meras repartições administrativas da única Igreja Universal ${ }^{16}$. E, por sua vez, a Igreja Local só é Igreja em comu-

\footnotetext{
${ }^{16}$ W. Kasper, Teologia e Chiesa, Queriniana, Brescia, 1989, p. 290.
} 
nhão com as demais Igrejas ( $A G$ 38) consideradas sincrônica e diacronicamente.

A Igreja Universal resulta assim da mútua recepção e comunhão das Igrejas Locais. Ela é a comunhão das Igrejas Locais. A expressão conciliar ( $L G 23$ ) "formadas à imagem da Igreja Universal" não significa serem constituídas como reprodução de uma Igreja "ideal", platonicamente concebida, que pudesse existir sem as Igrejas Locais ${ }^{17}$. Significa, isto sim, que a Igreja que resulta da comunhão das Igrejas Locais é idêntica à que se realiza nas Igrejas Locais. Aqui está o fundamento da comunhão das Igrejas. Há, portanto, uma mútua inclusão: não se pode conceber a Igreja Local sem a Igreja Universal, nem esta última é uma realidade sem as Igrejas Locais ${ }^{18}$. Este ponto deve ser frisado, pois inconscientemente, quando pensamos as relações entre as Igrejas Locais e a Igreja Universal, podemos identificar a Igreja Universal com a Igreja de Roma, imaginando uma relação entre periferia e centro, entre bispos e autoridade romana, como se a Igreja de Roma não fosse também uma Igreja Local. Tudo o que afirmamos da Igreja Universal, por exemplo, ser ela o sacramento universal da salvação $(L G 1)$, só existe realmente nas e pelas Igrejas Locais.

Observe-se ainda que o bispo não é o pastor de uma Igreja Local antes de ser membro do colégio dos bispos, nem vice-versa ${ }^{19}$. Assim ele mediatiza a Igreja Local com a Igreja Universal e esta com aquela. Nele estão presentes as duas dimensões da Igreja: particularidade e universalidade, localidade e catolicidade. Daí a responsabilidade de cada bispo pelas outras Igrejas ( $A G$ 38 ), concretizada na colaboração mútua e no afeto colegial ( $L G 23)$. Daí a importância da contribuição própria das Igrejas Locais para a catolicidade da Igreja Universal, que não é apenas formal (mesma constituição teológica), mas real ao apresentar configurações diversas das experiências cristãs e das comunidades de fé conforme o contexto onde estão e os desafios que enfren-

${ }^{17}$ J.A. Komonchak, "La Iglesia Local y la Iglesia Católica", em: H.Legrand-J.ManzanaresA.Garcia y Garcia (org.), Iglesias Locales y Catolicidad, Universidad Pontifícia de Salamanca, 1992 , p. 568 nota 23.

${ }^{18}$ Não desconhecemos o debate em torno de uma prioridade (ontológica) da Igreja Universal sobre as Igrejas Locais, o texto de Communionis notio $n .9$ e a tendência do Código de Direito Canônico de limitar em questões disciplinares a ação das Igrejas Locais. Tratar esta complexa questão nos afastaria de nosso objetivo. Uma visão atualizada, embora crítica, do tema nos traz H. Legrand, "The bischop in the Church and the Church in the Bischop", The Jurist 66 (2006) p. 70-92.

${ }^{19}$ A segunda parte da afirmação é negada tanto pelo Código de Direito Canônico (cânon 376) que distingue bispo diocesano e bispo titular como pela Carta Apostólica Apostolos Suos n. 12 nota 55. 
tam. A Igreja é católica (universal) por se voltar tanto para o desafio das religiões na Ásia, quanto para a pobreza na África, ou para a crítica da modernidade na Europa, ou ainda para os marginalizados na América Latina.

O papel da sede romana como sinal da unidade da Igreja é de fortalecer a comunhão entre as Igrejas Locais, não assumindo suas funções e suas competências, como se tratasse de uma entidade que tudo centralizasse, mas de supervisionar (episkopein) as Igrejas Locais para garantir sua comunhão e, assim, a unidade da Igreja de Jesus Cristo ${ }^{20}$. A história da Igreja nos demonstra que o exercício do primado pode variar no modo como é exercido. Conseqüentemente existe a possibilidade de se "encontrar uma forma de exercício" que "se abra a uma situação nova"21. Pois as Igrejas Locais são fundamentalmente sujeito $^{22}$. Embora historicamente a relação entre primado e episcopado pôde se apresentar numa certa tensão dialética, como se a ênfase num dos pólos enfraquecesse o outro, cuidar da unidade e da comunhão das Igrejas Locais não implica por si mesmo tal tensão. Pois, sendo a missão do primado a de fortalecer e de confirmar as Igrejas Locais na fé e na vivência da caridade, então a força e a unidade do episcopado indica a força e a eficácia do primado ${ }^{23}$. A excessiva centralização pode se tornar dominação e minar a força do episcopado, ou seja, contradizer a finalidade do próprio primado $^{24}$.

"A uniformidade do direito eclesiástico, a uniformidade da liturgia, o controle das sedes episcopais por parte de Roma, são realidades que não necessariamente provêm do primado como tal, mas derivam da união do munus primacial e patriarcal. Seria deveras interessante que, para o futuro se distinguisse novamente e com acurada clareza, a missão autêntica do sucessor de Pedro e a missão do patriarca e que, onde se fizesse necessário, se criassem novos patriarcados, sem considerá-los incorporados à Igreja latina. A aceitação da unidade com o papa não significaria mais partilhar de uma administração uniforme, mas significaria sim, inserir-se na unidade da fé e da communio" "25. A separação das funções petrinas e patriarcais pede uma

\footnotetext{
${ }^{20}$ João Paulo II, Ut unum sint n. 94.

${ }^{21}$ Ibid. n. 95.

${ }^{22}$ De tal modo que devem participar da nomeação de seus pastores. Ver J. Ratzinger, "Demokratisierung der Kirche?", em: J.Ratzinger-H.Maier, Demokratie in der Kirche, Lahn-Verlag, Limburg, p. 39s.

${ }^{23}$ M. Buckley, ob.cit. p.72s. Ver W. Klausnitzer, ob. cit. p. 448 nota 338, que menciona, nesta mesma linha, outros teólogos como Hünermann, Henn, Pottmeyer, Neuner.

${ }^{24}$ Ibid. p. $78 \mathrm{~s}$.

${ }^{25}$ J. Ratzinger, O Novo Povo de Deus, Paulinas, S. Paulo, 1974, p.138s.
} 
revisão da Cúria Romana ${ }^{26}$, cujas funções deveriam ser participadas pelo episcopado mundial, já que "o colégio dos bispos como tal, junto com o papa, poderia se considerar como superior à Cúria e cooperar para moldála"27. Observemos que a comunhão eclesial apresentada no Concílio Vaticano II pressupõe não só a colegialidade e a catolicidade, mas também a subsidiaridade.

\section{Igreja Local e movimentos}

Os movimentos deitam suas raízes na época anterior ao Concílio com o "Movimento por um mundo melhor" e com a Ação Católica. Textos conciliares contribuem para promover o apostolado leigo ${ }^{28}$, embora ainda numa perspectiva dualista entre hierarquia e laicato diversa da que temos hoje. De fato apenas se menciona o direito dos fiéis de se associarem e em comunhão com a hierarquia. Evangelii Nuntiandi (1975) considera "os ministérios diversificados dos leigos", vistos numa ótica apostólica como "preciosos para a implantação, a vida e o crescimento da Igreja". Deste modo, tais ministérios estavam não só a serviço da animação da ordem temporal, mas ainda da comunhão eclesial (EN 73). Grande incentivo receberão os movimentos no pontificado de João Paulo II. Sua primeira encíclica, Redemptor Hominis, já assinala que "um idêntico espírito de colaboração e de co-responsabilidade... se difundiu também entre os leigos, não apenas confirmando as organizações de apostolado laical já existentes, mas criando outras novas, que não raro se apresentam com um aspecto diferente e uma dinâmica especial ( $R H$ 5). Os anos posteriores apenas intensificam esta aprovação inicial nos diversos encontros sobre os movimentos.

Na Exortação Apostólica Christifideles Laici (1989) os movimentos são reconhecidos como "uma nova era agregativa dos fiéis leigos", agregações estas "bastante diferentes umas das outras", mas com "profunda convergência na finalidade que as anima: a de participar responsavelmente da missão da Igreja (ChL 29). De um lado, ressalta o direito que os leigos têm

\footnotetext{
${ }^{26}$ A competência da Curia Romana e dos bispos estava no centro das discussões que antecederam o Concílio Vaticano II. Ver Gilles Routhier, "Vatican II: the first Stage of an unfinished Process of reversing the centralized Gouvernment of the Catholic Church", The Jurist 64 (2004) p.259.

27 J. Ratzinger, "Konkrete Formen bischöflicher Kollegialität”, em: J. Chr. Hampe (Hrsg.), Ende der Gegenreformation? Das Konzil. Dokumente und Deutung, Kreuz, Stuttgart, 1964, p.158. Citado por Pottmeyer, Towards a Papacy in Communion, Herder, New York, 1998, p. 135.

${ }^{28}$ LG 30-38; GS 43; PO 8; e sobretudo o Decreto Apostolicam Actuositatem (AA).
} 
de se associarem na Igreja, que provém do batismo, e, de outro, apresenta cinco critérios de eclesialidade: o primado da vocação do cristão à santidade, a responsabilidade em professar a fé católica, o testemunho de uma comunhão sólida e convicta, a conformidade e a participação na finalidade apostólica da Igreja e o empenho de uma presença na sociedade humana (ChL 30). O apoio de João Paulo II aos movimentos se mantém nos anos sucessivos de seu pontificado, embora advertindo seminaristas e sacerdotes diocesanos, inseridos nos movimentos, sobre o respeito aos educadores e aos bispos (Pastores Dabo Vobis 68), como também lembrando aos religiosos e religiosas que necessitam do consentimento dos Superiores (Vita Consecrata 56).

Não é fácil caracterizar com precisão os novos movimentos, dadas as diferenças entre eles. Tentemos uma compreensão primeira deste fenômeno. Os novos movimentos eclesiais têm primeiramente sua origem no carisma de um fundador, que suscita em seus membros uma conversão existencial ao Evangelho e uma renovação radical do batismo recebido. Desse modo surge uma espiritualidade específica. Outra característica que os distingue é o fato de acolherem todas as categorias de pessoas: leigos casados ou não, religiosos e sacerdotes. Assim se distinguem dos movimentos leigos do passado, bem como das congregações religiosas, e mesmo das entidades de fiéis leigos afiliados às mesmas congregações. Como buscam viver o Evangelho em todos os âmbitos da vida humana, configuram uma comunhão eclesial, expressa numa estrutura institucional igual para todos, embora permitam certa flexibilidade de pertença para seus membros.

Uma terceira característica diz respeito à atividade apostólica dos novos movimentos, que os distingue dos "movimentos espirituais". São realmente movimentos eclesiais na medida em que procuram evangelizar publicamente mediante a própria comunhão eclesial que os constituiu, a qual abarca os diversos estados de vida. Finalmente mencionemos ainda a universalidade como traço também peculiar aos novos movimentos eclesiais, os quais abarcando todas as categorias de católicos chega em sua ação apostólica aos vários setores da sociedade incluindo o diálogo com membros de outras Igrejas cristãs e de outras religiões. Temos aqui algo realmente novo na história da Igreja e não nos deve admirar a dificuldade de se enquadrar canonicamente tais novos movimentos.

Se fossemos tentar explicar o surgimento deste fenômeno na Igreja deveríamos apontar primeiramente para a ação inspiradora do Espírito Santo que age como quer e quando quer para a salvação da humanidade. A tenacidade dos fundadores diante das dificuldades e incompreensões presentes nos primeiros anos confirma o que afirmamos. Mas o Espírito Santo não age 
num vazio eclesial. Sua ação irrompe para suprir deficiências, solucionar crises, corrigir unilateralidades, romper rotinas, reavivar vivências, numa palavra, para deixar melhor transparecer e ser acolhida a salvação de Jesus Cristo. Aceito isso, devemos entender os novos movimentos como uma interpelação à própria Igreja, no que ela é como instituição a serviço do Reino de Deus.

Já vimos como as profundas e rápidas mudanças socioculturais acabaram por afetar a própria Igreja em sua configuração institucional. A sociedade pluralista, a emergência da subjetividade na cultura, a hegemonia nefasta do fator econômico lançam novas exigências à Igreja, que experimenta os limites e as insuficiências da pastoral tradicional. Nossos contemporâneos demonstram sede de Deus e buscam um referencial firme para suas vidas, mas esse dinamismo se traduz, por vezes, numa religiosidade subjetiva, não eclesial, desenraizada de uma tradição. Os novos movimentos indicam a distância entre a Igreja e a sociedade e buscam, ao mesmo tempo, oferecer uma solução. Eles possibilitam espaços vitais, comunitários, ricos de relações pessoais entre os fiéis, que tanto fortalecem sua identidade cristã quanto os estimulam a viver a fé sob novas formas sociais.

Contudo devemos reconhecer que a questão do estatuto jurídico dos novos movimentos na Igreja ainda não recebeu uma resposta satisfatória e plena. Sendo um fenômeno novo o fator tempo desempenha aqui um papel importante. A legislação eclesiástica não pode ser aplicada simplesmente aos novos movimentos porque neles se encontram também religiosos|as e presbíteros. Mas compete ao bispo diocesano examinar e ajudar estas novas formas de vida consagrada, que deverão ser aprovadas pela Sé Apostólica (cânon 605). A maior semelhança delas é com a vida religiosa, já que apresentam alguns componentes da mesma, embora careçam de outros. O membro de um movimento responde também a um chamado de Deus no interior da Igreja e em vista de sua missão, mas não pode ser caracterizado plenamente como "consagrado pelos conselhos evangélicos" por lhe faltar a intervenção ministerial da Igreja que se faz mediadora da iniciativa divina e da resposta humana confiando-lhe também uma missão. Daí permanecerem os membros dos novos movimentos, mesmo assumindo conselhos evangélicos, no estado de leigos ou no estado clerical diocesano, embora com uma função profética em seu meio. Portanto, também se distinguem dos membros de institutos seculares que, leigos ou clérigos, pertencem ao estado de consagrados pela profissão dos conselhos evangélicos, com outros direitos e deveres específicos (cânones 573 e 574; 710-730).

Mais complexa é a questão da formação e da incardinação dos sacerdotes diocesanos. Quando formados no interior dos movimentos podem 
experimentar dificuldade em se entrosar com o restante do clero diocesano bem como com a pastoral da diocese. Quanto à incardinação, o Código de Direito Canônico não a permite num movimento, sendo assim realizada na diocese em acordo com o bispo, o que também pode apresentar dificuldades quando outro bispo assume a diocese.

A novidade maior dos novos movimentos está na diversidade de seus membros que reproduz assim a diversidade da comunidade eclesial. Nessa novidade está sua riqueza e simultaneamente sua dificuldade maior, pois poderiam se considerar uma "Igreja-Elite", contraposta a uma "IgrejaMassa", ou mesmo limitar a seu interior toda sua espiritualidade e missão. Estariam então caindo numa entidade de tipo seita, enquanto a Igreja se compreende como povo, Povo de Deus, que abraça a todos, santos e pecadores. Outra tentação poderia ser identificar o próprio movimento com a existência cristã sem mais, absolutizando-o e esquecendo ser ele, de fato, uma das várias formas de se viver o Evangelho. Também já foi observado que, em alguns casos, os movimentos se limitam demasiado à classe média, com menor empenho pelos pobres e excluídos da sociedade.

As novas comunidades que surgem em várias partes do Brasil representam uma questão mais complexa, pois se apresentam ainda como associações recentes, instáveis, carecendo de estatutos apropriados, de fundamentação teológica ou de vinculação eclesiológica, agrupadas em torno de uma forte liderança carismática e dotadas de grande entusiasmo. Certamente enquanto são associações laicais privadas, gozam de pleno direito de se constituírem, mas, caso elas se tornem um empecilho para as atividades paroquiais ou diocesanas, caberá ao bispo procurar trazê-las para a comunidade eclesial.

Por sua vez, o bispo diocesano deve estar aberto ao novo, mesmo que extrapole organizações e programações pastorais, pois não se deve extinguir o Espírito $(1 \mathrm{Ts} 5,19)$, mas examinar e discernir se a novidade contribui para o bem da comunidade eclesial e para sua finalidade salvífica. Este procedimento pode requerer tempo para que seus frutos amadureçam. Talvez este tempo seja marcado por tensões e conflitos, que deverão ser suportados na fé até que ambas as partes cresçam no mútuo conhecimento e respeito, bem como na vivência dos valores evangélicos. Sem dúvida, compete ao bispo a última palavra em sua diocese por exercer o carisma supremo da unidade. Cabe-lhe ajudar aos próprios movimentos a concretizarem fielmente os impulsos do Espírito, caso se faça necessário. Deve fazê-lo, mesmo se com correções, mas com compreensão e respeito por um dom do Espírito. 


\section{Conclusão}

Na Igreja Local compete ao bispo o governo da mesma. Tarefa da teologia é oferecer subsídios para uma tomada de posição conforme a situação concreta a permita. Sentimos viver ainda uma época marcada por certa centralização romana e pela promoção de movimentos supra-diocesanos. Não negamos as tensões que daí decorrem. É importante nesta hora mantermos a liberdade interior para evitar opções precipitadas. É importante igualmente que não percamos de vista a finalidade última da Igreja. Sua ação salvífica acontece primordialmente na Igreja Local. Portanto, é fundamental que seu contexto existencial e sociocultural seja respeitado em vista de uma pastoral profícua e eficaz. Portanto, na perspectiva da teologia se impõe hoje uma pastoral inculturada a ser realizada por todos: bispos, párocos, movimentos, religiosos/as e leigos/as.

\section{Abstract}

The paper presents, after describing some features of the present society, the theological constitutives points of the Church and their necessary institutional configuration. After this, it indicates the relationship between the Local Church with the Universal Church. And, to conclude, it speaks by the question about the movements in the Local Church.

Mario de França Miranda Doutor pela Pontificia Universidade Gregoriana Professor do Departamento de Teologia da PUC-Rio 